ORIGINAL ARTICLE

\title{
Chronic Kidney Disease in the Caribbean Island of Antigua: Causes, Morbidity and Mortality Factors
}

\author{
G Meade $^{1}$, AK Soyibo ${ }^{2}$, M Lawrence-Wright ${ }^{3}$, T Ferguson ${ }^{4}$, I Thomas ${ }^{1}$
}

\begin{abstract}
Background: Chronic kidney disease (CKD) and its associated high morbidity and mortality cause a significant economic burden and decreased quality of life in affected patients in Antigua, the rest of the Caribbean and globally. The causes of CKD in Antigua, morbidity and mortality factors affecting the sampled patients were evaluated with a view to formulating interventions to minimize the occurrence and the impact of these factors.

Objective: To determine the causes of CKD over a nine-year period and the causes of morbidity and mortality among patients with CKD at the two main hospitals in Antigua.

Methods: A retrospective review was done of the medical records of patients with CKD who were diagnosed between January 1, 2005 and December 1, 2013. Chronic kidney disease was defined as a glomerular filtration rate of less than $60 \mathrm{~mL} /$ minute $/ 1.73 \mathrm{~m}^{2}$. The causes of CKD, the patients'admission diagnoses, the causes of death and laboratory investigations were evaluated.

Results: The documented causes of CKD in these patients were diabetes mellitus (51\% of the patients), hypertension (26\%), glomerulonephritis (5\%) and lupus nephritis (4\%). The causes of morbidity among the patients with CKD were myocardial infarction (5.1\%), unstable angina (12.7\%) and ischaemic stroke (12\%). Contributing significantly to the patients' morbidity were catheter-associated sepsis $(8.1 \%, \mathrm{p}<0.001)$ and lower respiratory tract infections $(5.4 \%)$. The main factors contributing to the patients' mortality were myocardial infarction (16.7\%) and catheter-associated sepsis (16.7\%).

Conclusion: This study documented that the most common causes of CKD among the sampled patients in Antigua were diabetes mellitus and hypertension. Ischaemic heart disease and infections were the major causes of morbidity and mortality among the patients. Early recognition and aggressive management of CKD and its risk factors and complications are important in reducing the clinical and economic burden associated with CKD.
\end{abstract}

Keywords: Antigua, Caribbean, chronic kidney disease, diabetes mellitus, hypertension, ischaemic heart disease

From: 'Mount St John's Medical Centre, Antigua, West Indies, ${ }^{2}$ Department of Medicine, University Hospital of the West Indies and The University of the West Indies, Mona, Kingston, and Caribbean Institute of Nephrology, Jamaica, West Indies, ${ }^{3}$ Department of Medicine, University Hospital of the West Indies and The University of the West Indies, Mona, Kingston, Jamaica, West Indies and ${ }^{4}$ Epidemiology Research Unit, Caribbean Institute for Health
Research, The University of the West Indies, Mona, Kingston, Jamaica, West Indies.

Correspondence: Dr AK Soyibo, Department of Medicine, The University of the West Indies, Mona, Kingston 7, Jamaica, West Indies. Email: demoskey@hotmail.com 


\title{
Enfermedad renal crónica en la isla caribeña de Antigua: causas, morbilidad y factores de mortalidad
}

\author{
G Meade $^{1}$, AK Soyibo ${ }^{2}$, M Lawrence-Wright ${ }^{3}$, T Ferguson ${ }^{4}$, I Thomas ${ }^{1}$
}

\begin{abstract}
RESUMEN
Antecedentes: La enfermedad renal crónica (ERC) y su alta morbilidad y mortalidad asociadas, son causa de una importante carga económica y disminución de la calidad de vida entre los pacientes afectados en Antigua, el resto del Caribe y en todo el mundo. Se evaluaron las causas de la ERC en Antigua, así como los factores de morbilidad y mortalidad que afectan a los pacientes muestreados, con el fin de formular intervenciones encaminadas a minimizar la ocurrencia y el impacto de estos factores.

Objetivo: Determinar las causas de la ERC durante un período de nueve años y las causas de morbilidad y mortalidad entre pacientes con ERC en los dos principales hospitales de Antigua.

Métodos: Se realizó una revisión retrospectiva de las historias clínicas de los pacientes con ERC diagnosticados entre el 1 de enero de 2005 y el 1 de diciembre de 2013. La enfermedad renal crónica se definió como una tasa de filtración glomerular inferior a $60 \mathrm{ml} / \mathrm{minuto} / 1.73 \mathrm{~m}^{2}$. Se evaluaron las causas de la ERC, los diagnósticos de admisión de los pacientes, así como las causas de muerte y las investigaciones de laboratorio.

Resultados: Las causas documentadas de la ERC en estos pacientes fueron la diabetes mellitus (51\% de los pacientes), la hipertensión (26\%), la glomerulonefritis (5\%), y la nefritis lúpica (4\%). Las causas de morbilidad entre los pacientes con ERC fueron el infarto de miocardio (5.1\%), la angina inestable (12.7\%) y el accidente cerebrovascular isquémico (12\%). La sepsis asociada con catéter $(8.1 \%, \mathrm{p}<0.001)$ y las infecciones de las vías respiratorias inferiores (5.4\%) contribuyeron significativamente a la morbilidad de los pacientes. Los principales factores que contribuyeron a la mortalidad de los pacientes fueron el infarto del miocardio (16.7\%) y la sepsis asociada con catéter (16.7\%).

Conclusión: Este estudio documentó que las causas más comunes de ERC entre los pacientes incluidos en la muestra en Antigua fueron la diabetes mellitus y la hipertensión. La enfermedad cardiaca isquémica y las infecciones fueron las principales causas de morbilidad y mortalidad entre los pacientes. El diagnóstico temprano y el tratamiento agresivo de la ERC y sus factores y complicaciones de riesgo, son asuntos de importancia a la hora de reducir la carga clínica y económica asociadas con ERC.
\end{abstract}

Palabras clave: Antigua, caribeño, enfermedad renal crónica, diabetes mellitus, hipertensión, enfermedad cardíaca isquémica

West Indian Med J 2018; 67 (2): 174

\section{INTRODUCTION}

According to the Kidney Disease: Improving Global Outcomes (KDIGO) Work Group, chronic kidney disease (CKD) is defined as kidney damage for more than three months with a loss of glomerular function or a glomerular filtration rate below $60 \mathrm{ml} /$ minute $/ 1.73 \mathrm{~m}^{3}$ and/or the presence of albuminuria ( $>30 \mathrm{mg}$ ) (1). Globally, CKD has a high rate of healthcare utilization, morbidity and mortality; hence, CKD constitutes a significant economic and clinical burden on the healthcare system. Although the incidence and prevalence of endstage renal disease (ESRD) differ substantially across countries and regions, its estimated prevalence worldwide was $8-16 \%(1)$.

More than $80 \%$ of all patients receiving treatment for ESRD are estimated to be in affluent countries with universal access to healthcare. The lower figures reported from less wealthy countries are largely due to patients not being accepted into renal replacement therapy (RRT) programmes, as is the situation in Antigua. The 
prevalence of CKD is expected to increase significantly worldwide as the population ages and the numbers of elderly people increase. This will be compounded by the rising prevalence of the precursors of CKD, ie hypertension and diabetes mellitus. The worldwide prevalence of less symptomatic or asymptomatic early-stage CKD, which accounts for $80-90 \%$ of all cases, is unknown and difficult to ascertain. The data had been confounded by the heterogeneity in the populations screened, methods used to determine glomerular filtration rates and proteinuria assays used (1).

Globally, diabetes mellitus is the most common cause of CKD, but in some regions, other causes (such as herbal and environmental toxins) are more common. Data from the Caribbean Renal Registry have also identified hypertension and diabetes mellitus as the leading causes of CKD and ESRD in the Caribbean (2). The contribution of these conditions varies throughout the Caribbean (2). According to the Global Burden of Disease Study 2010, CKD was ranked $27^{\text {th }}$ in the list of the causes of the total number of global deaths in 1990 (age-standardized annual death rate of 15.7 per 100000 ), but rose to $18^{\text {th }}$ in 2010 (annual death rate of 16.3 per 100000 ) (3). This degree of movement up the list was second only to that for HIV and AIDS. The overall increase in the years of life lost due to premature mortality $(82 \%)$ was the third largest, behind HIV and AIDS (396\%) and diabetes mellitus (93\%) (3).

The factors influencing the morbidity and mortality in patients with renal disease are present prior to the onset of dialysis. These include anaemia, hypertension, malnutrition, mineral and bone disorders, and lipid abnormalities. Inadequate renal screening and delayed referral of patients with CKD usually lead to an increased occurrence of emergency dialysis with its associated higher morbidity and mortality. The mortality in this crisis situation can be as high as $25 \%$ (4).

Cardiovascular mortality accounts for $40-50 \%$ of deaths in dialysis patients. Patients with diabetes mellitus face an especially severe cardiovascular risk, which contributes to reduced survival on dialysis (4). Once a diagnosis of $\mathrm{CKD}$ has been made, relevant risk factors should be immediately identified and treated. These factors affecting survival include hypertension, diabetes mellitus, cardiovascular disease, cigarette-smoking and chronic anaemia. Increasing evidence suggests that aggressive treatment of hypertension in the pre-dialysis period delays the progression of CKD and is the most potent intervention to decrease subsequent cardiovascular mortality in dialysis patients (4).
Infection remains a major cause of death in $15-30 \%$ of all dialysis patients and is usually access-related (4). Uraemia also impairs cell-mediated immunity and is not reversed completely by dialysis. Malnutrition is another important co-morbid condition contributing to mortality. Chronic kidney disease-associated mineral bone disorders and electrolyte abnormalities also contribute significantly to the morbidity and mortality in patients with CKD. Disturbances in body calcium, phosphorus, Vitamin D, parathyroid hormone and bone disease usually start prior to the initiation of dialysis and demand consistent attention.

Global, regional and local policies need to consider not only the increasing prevalence of non-communicable diseases of which diabetes mellitus, hypertension, cardiovascular disease and CKD make up a significant proportion, but also how to curtail the increasing prevalence of these conditions and to identify these diseases including CKD at an early stage.

Screening and intervention can prevent CKD, and where management strategies have been implemented, the progression to ESRD can be reduced. Also of importance is the development of the complications of CKD which increase patients' morbidity and mortality exponentially. Due to the increasing incidence of CKD and ESRD worldwide, internists and general practitioners have to be educated regarding the management of patients with CKD so as to limit the progression of the disease and its development and to institute appropriate treatment of the complications. The strategies to reduce the burden and costs related to CKD need to be included in the national programmes for non-communicable diseases.

This study proposed to evaluate the contribution of some factors leading to morbidity and mortality among selected patients with CKD in Antigua and to evaluate the causes of CKD and ESRD in Antigua.

We hypothesized that the prevalence of hypertension and diabetes mellitus in patients with CKD in Antigua would be similar to that seen in the rest of the Caribbean. Furthermore, we hypothesized that there would be no difference in the cardiovascular disease burden in Antigua than globally and in the Caribbean.

\section{SUBJECTS AND METHODS}

A retrospective review of the medical records of patients with CKD at the Mount St John's Medical Centre (MSJMC) and Holberton Hospital in Antigua over a nine-year period was conducted. Ethical approval for the study was granted by The University of the West Indies 
Ethics Committee and the ethics committees of MSJMC and Holberton Hospital in Antigua. All the deaths and causes of death are kept at the Antigua Death Registry so permission was sought to review the records, and a tabulation of the causes of the deaths was recorded and the data analysed. All the medical records were kept confidential.

\section{Inclusion criteria}

Patients diagnosed with CKD (a glomerular filtration rate of $<60 \mathrm{ml} /$ minute $/ 1.73 \mathrm{~m}^{2}$ for three months or longer) between January 1, 2005 and December 1, 2013 were included in this study. Participants must have been treated at the MSJMC or at Holberton Hospital in Antigua.

\section{Exclusion criteria}

Patients whose medical records were not available for review, pregnant women and patients under 18 years old were excluded for this study.

\section{Data collected}

The data collected included the patients' demographics (such as age and gender), blood investigations (when admitted and discharged), chronic illnesses, causes of CKD, whether on RRT or not, discharge diagnoses and causes of death (Appendix).

\section{Statistical analyses}

The data collected were entered into Microsoft Excel software and subsequently converted to Stata format and analysed using Stata version 12. Means and proportions were obtained for clinical characteristics by gender. The differences in the proportions were compared using Fisher's Exact and Chi-square tests. A $p$-value of less than 0.05 was used to indicate statistical significance.

\section{RESULTS}

A total of 196 patients who attended the Holberton Hospital and MSJMC Medical Outpatient Clinic between 2005 and 2013 were noted to have stage III or more advanced CKD. Only 161 patients' medical records were available for review, from which the relevant patients' data were extracted.

There were 89 males and 72 females with an average age at diagnosis of $56.2 \pm 1.7$ years for males and $59 \pm$ 1.9 years for females (Table 1 ).

\section{Laboratory values at diagnosis}

Average creatinine (umol/L) at diagnosis was 697.0 \pm 82.9 for males and $434.5 \pm 55.5$ for females. Urea $(\mathrm{mmol} / \mathrm{L})$ was $22.6 \pm 15.4$ for males and $16.8 \pm 8.6$ for females. Calcium $(\mathrm{mmol} / \mathrm{L})$ was $2.1 \pm 0.3$ for males and $2.3 \pm 0.3$ for females. Albumin $(\mathrm{g} / \mathrm{L})$ was $34 \pm 8.7$ for males and $33 \pm 7.3$ for females. Phosphorus ( $\mathrm{mmol} / \mathrm{L}$ ) was $1.7 \pm 0.7$ for males and $1.3 \pm 0.3$ for females. Uric acid $(\mathrm{mmol} / \mathrm{L})$ was $8.2 \pm 2.0$ for males and $7.8 \pm 1.8$ for females. Average haemoglobin (g/dL) was $10.2 \pm 2.4$ for males and $9.6 \pm 1.7$ for females (Table 1).

\section{Laboratory values on discharge}

On discharge, the patients' creatinine (umol/L) was $665.6 \pm 505.0$ for males and $581.9 \pm 396.5$ for females. Calcium $(\mathrm{mmol} / \mathrm{L})$ was $2.2 \pm 0.3$ for males and $2.2 \pm$ 0.3 for females. Phosphorus (mmol/L) was $1.6 \pm 0.6$ for males and $1.4 \pm 0.4$ for females. Urea reduction ratios (URRs) (\%) were $65.2 \pm 11.3$ for males and $72.9 \pm 11.4$ for females (Table 1).

Table 1: Characteristics of the study's participants

\begin{tabular}{|c|c|c|c|c|}
\hline Characteristic & Male & Female & Total & $p$-value \\
\hline Present age (years) & $59.4 \pm 15.9$ & $61.9 \pm 15.7$ & $60.5 \pm 15.8$ & 0.307 \\
\hline $\begin{array}{l}\text { Age at diagnosis } \\
\text { (years) }\end{array}$ & $56.2 \pm 1.7$ & $59.0 \pm 1.9$ & $57.4 \pm 1.3$ & 0.247 \\
\hline $\begin{array}{l}\text { Serum creatinine at } \\
\text { diagnosis (umol/L) }\end{array}$ & $697.0 \pm 82.9$ & $434.5 \pm 55.5$ & $580.1 \pm 53.1$ & 0.009 \\
\hline $\begin{array}{l}\text { Serum urea at } \\
\text { diagnosis }(\mathrm{mmol} / \mathrm{L})\end{array}$ & $22.6 \pm 15.4$ & $16.8 \pm 8.6$ & $20.0 \pm 13.0$ & 0.004 \\
\hline $\begin{array}{l}\text { Haemoglobin at } \\
\text { diagnosis }(g / d L)\end{array}$ & $10.2 \pm 2.4$ & $9.6 \pm 1.7$ & $9.9 \pm 2.1$ & 0.077 \\
\hline $\begin{array}{l}\text { Potassium at } \\
\text { diagnosis }(\mathrm{mmol} / \mathrm{L})\end{array}$ & $4.8 \pm 0.9$ & $4.5 \pm 0.8$ & $4.6 \pm 0.9$ & 0.032 \\
\hline $\begin{array}{l}\text { Corrected calcium } \\
\text { at diagnosis } \\
(\mathrm{mmol} / \mathrm{L})\end{array}$ & $2.1 \pm 0.3$ & $2.3 \pm 0.3$ & $2.2 \pm 0.3$ & 0.030 \\
\hline $\begin{array}{l}\text { Albumin at } \\
\text { diagnosis }(\mathrm{g} / \mathrm{L})\end{array}$ & $34 \pm 8.7$ & $33 \pm 7.3$ & $33.5 \pm 8.0$ & 0.537 \\
\hline $\begin{array}{l}\text { Uric acid at } \\
\text { diagnosis }(\mathrm{mmol} / \mathrm{L})\end{array}$ & $8.2 \pm 2.0$ & $7.8 \pm 1.8$ & $8.0 \pm 1.9$ & 0.381 \\
\hline $\begin{array}{l}\text { Phosphorus at } \\
\text { diagnosis (mmol/L) }\end{array}$ & $1.7 \pm 0.7$ & $1.3 \pm 0.3$ & $1.5 \pm 0.6$ & 0.003 \\
\hline $\begin{array}{l}\text { Right kidney size } \\
(\mathrm{cm})\end{array}$ & $9.9 \pm 1.7$ & $9.9 \pm 1.3$ & $9.9 \pm 1.5$ & 0.977 \\
\hline $\begin{array}{l}\text { Left kidney size } \\
(\mathrm{cm})\end{array}$ & $10.1 \pm 1.8$ & $10.0 \pm 1.2$ & $10.1 \pm 1.5$ & 0.706 \\
\hline $\begin{array}{l}\text { Creatinine on } \\
\text { discharge (umol/L) }\end{array}$ & $665.6 \pm 505.0$ & $581.9 \pm 396.5$ & $628.4 \pm 460.4$ & 0.250 \\
\hline $\begin{array}{l}\text { Urea reduction ratio } \\
\text { on discharge }\end{array}$ & $65.2 \pm 11.3$ & $72.9 \pm 11.4$ & $68.4 \pm 10.6$ & 0.004 \\
\hline $\begin{array}{l}\text { Corrected calcium } \\
\text { on discharge } \\
(\mathrm{mmol} / \mathrm{L})\end{array}$ & $2.2 \pm 0.3$ & $2.2 \pm 0.3$ & $2.2 \pm 0.3$ & 0.354 \\
\hline $\begin{array}{l}\text { Albumin on } \\
\text { discharge }(\mathrm{g} / \mathrm{L})\end{array}$ & $38.4 \pm 7.0$ & $37.6 \pm 5.3$ & $38.0 \pm 6.3$ & 0.544 \\
\hline $\begin{array}{l}\text { Phosphorus on } \\
\text { discharge }(\mathrm{mmol} / \mathrm{L})\end{array}$ & $1.6 \pm 0.6$ & $1.4 \pm 0.4$ & $1.5 \pm 0.6$ & 0.171 \\
\hline Body mass index & $25.2 \pm 4.5$ & $27.0 \pm 5.0$ & $26.0 \pm 4.8$ & 0.204 \\
\hline
\end{tabular}


Characteristics of patients on renal replacement therapy versus those not on renal replacement therapy

The age at diagnosis for patients on RRT was 49.2 \pm 15.3 years versus $64.8 \pm 14.0$ for those not on it (Table 2). Creatinine (umol/L) at diagnosis was $926.7 \pm$ 763.0 for patients requiring RRT and $235.8 \pm 112.8$ for those not requiring it. Average haemoglobin $(\mathrm{g} / \mathrm{dL})$ at diagnosis was $8.7 \pm 1.7$ for patients on RRT versus 11.0 \pm 1.9 for those who were not. Calcium $(\mathrm{mmol} / \mathrm{L})$ was $2.0 \pm 0.4$ for patients on RRT versus $2.3 \pm 0.2$ for those

Table 2: Characteristics of patients on renal replacement therapy versus those not on renal replacement therapy

\begin{tabular}{lccc}
\hline Characteristic & $\begin{array}{c}\text { Patients } \\
\text { on renal } \\
\text { replacement } \\
\text { therapy }\end{array}$ & $\begin{array}{c}\text { Patients not } \\
\text { on renal } \\
\text { replacement } \\
\text { therapy }\end{array}$ & \\
\hline Present age (years) & $53.3 \pm 14.5$ & $67.4 \pm 14.0$ & $<0.001$ \\
Age at diagnosis (years) & $49.2 \pm 15.3$ & $64.8 \pm 14.0$ & $<0.001$ \\
Creatinine at diagnosis (umol/L) & $926.7 \pm 763.0$ & $235.8 \pm 112.8$ & $<0.001$ \\
Urea at diagnosis (mmol/L) & $26.4 \pm 14.8$ & $13.4 \pm 6.0$ & $<0.001$ \\
Haemoglobin at diagnosis $(\mathrm{g} / \mathrm{dL})$ & $8.7 \pm 1.7$ & $11.0 \pm 1.9$ & $<0.001$ \\
Potassium at diagnosis $(\mathrm{mmol} / \mathrm{L})$ & $4.7 \pm 0.9$ & $4.5 \pm 0.8$ & 0.223 \\
Corrected calcium at diagnosis & $2.0 \pm 0.4$ & $2.3 \pm 0.2$ & $<0.001$ \\
(mmol/L) & & & \\
Albumin at diagnosis $(\mathrm{g} / \mathrm{L})$ & $31.2 \pm 9.0$ & $35.3 \pm 6.8$ & 0.016 \\
Uric acid at diagnosis $(\mathrm{mmol} / \mathrm{L})$ & $8.3 \pm 1.7$ & $7.9 \pm 2.1$ & 0.426 \\
Phosphorus at diagnosis $(\mathrm{mmol} / \mathrm{L})$ & $1.9 \pm 0.6$ & $1.3 \pm 0.4$ & $<0.001$ \\
Right kidney size $(\mathrm{cm})$ & $9.7 \pm 1.7$ & $10.1 \pm 1.4$ & 0.234 \\
Left kidney size $(\mathrm{cm})$ & $9.7 \pm 1.7$ & $10.4 \pm 1.3$ & 0.045 \\
Creatinine on discharge (umol/L) & $992.9 \pm 307.0$ & $263.6 \pm 131.7$ & $<0.001$ \\
Corrected calcium on discharge & $2.1 \pm 0.3$ & $2.4 \pm 0.2$ & $<0.001$ \\
(mmol/L) & & & \\
Albumin on discharge $(\mathrm{g} / \mathrm{L})$ & $38.6 \pm 5.7$ & $37.7 \pm 6.9$ & 0.462 \\
Phosphorus on discharge (mmol/L) & $1.6 \pm 0.6$ & $1.3 \pm 0.3$ & 0.005 \\
\hline
\end{tabular}

Table 3: Causes of chronic kidney disease for males, females and total sample

\begin{tabular}{lccc}
\hline Cause & $\begin{array}{c}\text { Males } \\
\text { Number (\%) }\end{array}$ & $\begin{array}{c}\text { Females } \\
\text { Number (\%) }\end{array}$ & $\begin{array}{c}\text { Total } \\
\text { Number (\%) }\end{array}$ \\
\hline Diabetes mellitus (DM) & $32(47.7)$ & $31(45.4)$ & $63(50.8)$ \\
Hypertension (HTN) & $16(23.9)$ & $16(28.1)$ & $32(25.8)$ \\
DM and HTN & $2(3)$ & $1(1.8)$ & $3(2.4)$ \\
Lupus nephritis & 0 & $5(8.8)$ & $5(4.0)$ \\
HIV & $1(1.5)$ & 0 & $1(0.8)$ \\
Polycystic kidney disease & $2(3.0)$ & 0 & $2(1.6)$ \\
Glomerulonephritis & $3(4.5)$ & $3(5.3)$ & $6(4.9)$ \\
Obstructive uropathy & $3(4.5)$ & 0 & $3(2.4)$ \\
Other* & $8(11.9)$ & $1(1.8)$ & $9(7.3)$ \\
Total & 67 & 57 & $124 * *$ \\
\hline
\end{tabular}

* Includes urate nephropathy, posterior urethral valves, focal segmental glomerulosclerosis.

** No cause of CKD/ESRD was documented for 37 patients. not on RRT. Albumin (g/L) was $31.2 \pm 9.0$ for patients on RRT versus $35.3 \pm 6.8$ for those who were not.

\section{Causes of chronic kidney disease in Antigua}

It was noted that the causes of CKD in the study participants were diabetes mellitus (51\% of the patients), hypertension $(26 \%)$, glomerulonephritis $(5 \%)$, lupus nephritis (4\%), diabetes and hypertension ( $2 \%)$, obstructive uropathy $(2 \%)$, polycystic kidney disease $(2 \%)$, HIV (1\%), and other causes (7\%) (Fig. 1, Table 3). Other causes included urate nephropathy, posterior urethral valves and focal segmental glomerulosclerosis. No cause of CKD/ESRD was documented for 37 patients.

\section{Vascular access types}

At the time of data collection in $2014,81 \%$ of the patients had arteriovenous (AV) fistulas, 16\% had permanent catheters and 3\% had temporary catheters (internal jugular vein and right femoral vein) (Fig. 2).

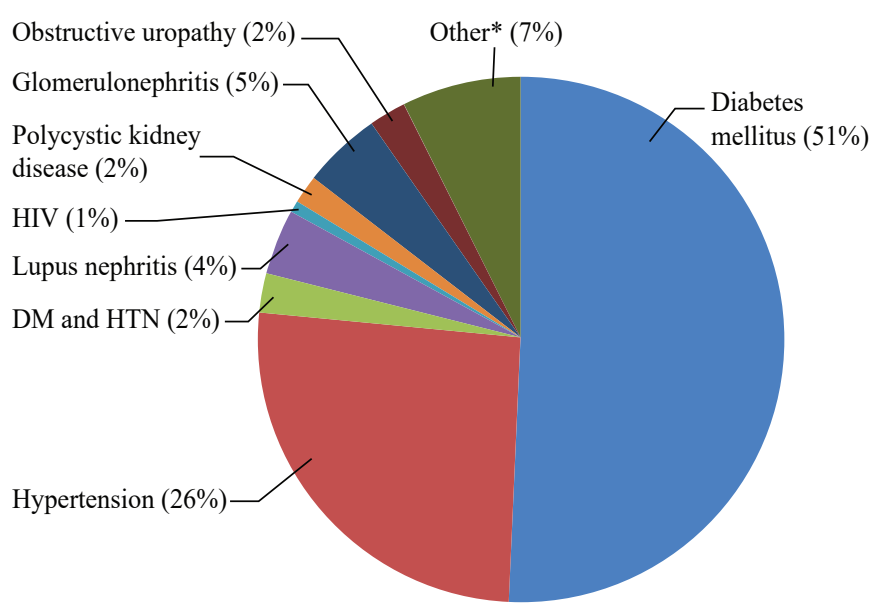

Fig. 1: Causes of chronic kidney disease in Antigua $(n=161)$.

* Includes urate nephropathy, posterior urethral valves and focal segmental glomerulosclerosis.

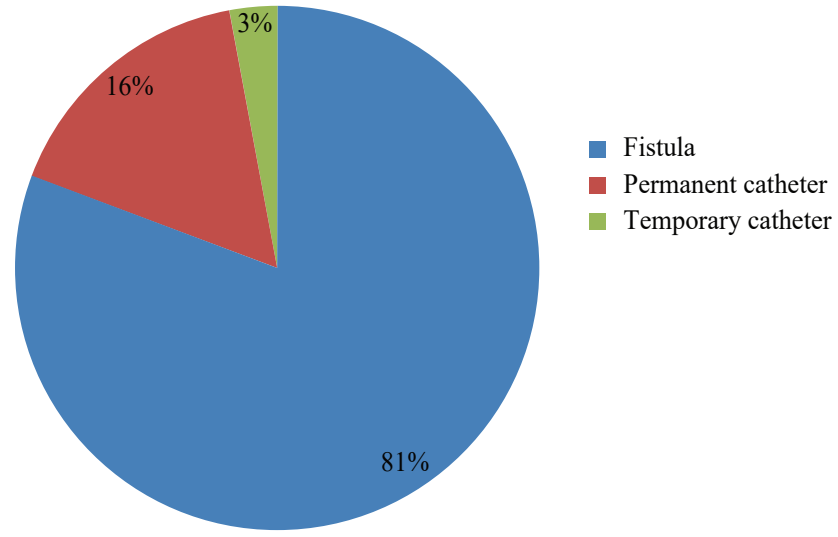

Fig. 2: Types of vascular access. 


\section{Causes of death among patients with chronic kidney disease in Antigua}

Myocardial infarction and catheter sepsis each accounted for $16.7 \%$ of the deaths. Stroke and other infections (non-catheter-related) accounted for $11.1 \%$ of the deaths. Other causes of death included intestinal obstruction, multiple myeloma and oesophageal varices (Table 4).

\section{Prevalence of stages of chronic kidney disease}

Of the patients studied, $33.12 \%$ had CKD stage III, $25.32 \%$ CKD stage IV and $41.56 \%$ CKD stage V (Table 5). Overall, $38.5 \%$ of the patients were on RRT. Of the patients with CKD stage V, 92.5\% were on RRT (Table 6).

\section{Number of patients diagnosed with chronic kidney disease per year}

The number of patients diagnosed with CKD per year at MSJMC increased from 2006 to 2010 and decreased from 2011 to 2013 (Table 7).

\section{Mortality rates}

A comparison was made to assess mortality between patients who received haemodialysis (HD) twice a week versus those who received HD three times a week. It was noted that the mortality percentage for the former (twice a week) was $18.42 \%$ versus $12.9 \%$ for the latter (three times a week).

For the patients on RRT via a catheter, the mortality rate was $21.43 \%$ versus $16.95 \%$ for those on RRT using a different type of vascular access (Fisher's exact $=0.705)$.

Table 4: Causes of death among patients with chronic kidney disease in Antigua by gender

\begin{tabular}{lccc}
\hline Causes of death & $\begin{array}{c}\text { Males } \\
\text { Number }(\%)\end{array}$ & $\begin{array}{c}\text { Females } \\
\text { Number }(\%)\end{array}$ & $\begin{array}{c}\text { Total } \\
\text { Number (\%) }\end{array}$ \\
\hline Myocardial infarction & $2(28.6)$ & $1(9.1)$ & $3(16.7)$ \\
Catheter sepsis & $1(14.3)$ & $2(18.2)$ & $3(16.7)$ \\
Other infections* & $1(14.3)$ & $1(9.1)$ & $2(11.1)$ \\
Stroke & $1(14.3)$ & $1(9.1)$ & $2(11.1)$ \\
Other** & $2(28.6)$ & $6(54.6)$ & $8(44.5)$ \\
Total & 7 & 11 & 18 \\
\hline
\end{tabular}

* Includes lower respiratory tract infections, urinary tract infections, infective endocarditis and infected diabetic foot.

** Includes intestinal obstruction, multiple myeloma and oesophageal variceal bleed.

Table 5: Prevalence of stages of chronic kidney disease in Antigua

\begin{tabular}{lcc}
\hline Stage & Number of patients & Percentage \\
\hline III & 53 & 32.92 \\
IV & 41 & 25.47 \\
V & 67 & 41.61 \\
\hline
\end{tabular}

Mean haemoglobin, calcium and phosphorus by chronic kidney disease stage

The haemoglobin levels at diagnosis for patients in CKD stages III, IV and V were $11.3 \pm 1.74,10.3 \pm 1.97$ and $8.58 \pm 1.80 \mathrm{~g} / \mathrm{dL}$, respectively. When discharged, their haemoglobin levels were $11.1 \pm 1.75,10.7 \pm 1.70$ and $10.5 \pm 1.73 \mathrm{~g} / \mathrm{dL}$, respectively.

The calcium levels at diagnosis for patients in CKD stages III, IV and V were $2.3 \pm 0.17,2.3 \pm 0.13$ and 1.97 $\pm 0.39 \mathrm{mmol} / \mathrm{L}$, respectively. Their final calcium levels when discharged were $2.3 \pm 0.17,2.2 \pm 0.31$ and $2.1 \pm$ $0.31 \mathrm{mmol} / \mathrm{L}$, respectively. The phosphorus levels at diagnosis for patients in CKD stages III, IV and V were 1.3 $\pm 0.43,1.3 \pm 0.27$ and $1.9 \pm 0.64 \mathrm{mmol} / \mathrm{L}$, respectively. Their phosphorus levels when discharged were $1.3 \pm 0.39$, $1.5 \pm 0.37$ and $1.6 \pm 0.6 \mathrm{mmol} / \mathrm{L}$, respectively (Table 8).

Table 6: Patients with stage $\mathrm{V}$ chronic kidney disease and renal replacement therapy

\begin{tabular}{lcc}
\hline & Number of patients* & Percentage \\
\hline $\begin{array}{l}\text { Not on renal } \\
\text { replacement therapy }\end{array}$ & 3 & 4.48 \\
$\begin{array}{l}\text { On renal replacement } \\
\text { therapy }\end{array}$ & 62 & 92.5 \\
\hline
\end{tabular}

* Renal replacement therapy data missing for two patients.

Table 7: Number of patients diagnosed with chronic kidney disease per year

\begin{tabular}{lc}
\hline Year & Number of patients \\
\hline $1997-2004$ & 7 \\
2005 & 5 \\
2006 & 1 \\
2007 & 4 \\
2008 & 8 \\
2009 & 26 \\
2010 & 44 \\
2011 & 36 \\
2012 & 23 \\
2013 & 7 \\
\hline
\end{tabular}

Table 8: Mean haemoglobin, calcium and phosphorus by stage of chronic kidney disease

\begin{tabular}{lcccc}
\hline Characteristic & Stage III & Stage IV & Stage V & $p$-value* \\
\hline $\begin{array}{l}\text { Haemoglobin at } \\
\text { diagnosis }\end{array}$ & $11.3 \pm 1.74$ & $10.3 \pm 1.97$ & $8.58 \pm 1.80$ & $<0.001$ \\
$\begin{array}{l}\text { Haemoglobin on } \\
\text { discharge }\end{array}$ & $11.1 \pm 1.75$ & $10.7 \pm 1.70$ & $10.5 \pm 1.73$ & 0.189 \\
$\begin{array}{l}\text { Calcium at } \\
\text { diagnosis }\end{array}$ & $2.3 \pm 0.17$ & $2.3 \pm 0.13$ & $1.97 \pm 0.39$ & $<0.001$ \\
$\begin{array}{l}\text { Calcium on } \\
\text { discharge }\end{array}$ & $2.3 \pm 0.17$ & $2.2 \pm 0.31$ & $2.1 \pm 0.31$ & $<0.001$ \\
$\begin{array}{l}\text { Phosphorus at } \\
\text { diagnosis }\end{array}$ & $1.3 \pm 0.43$ & $1.3 \pm 0.27$ & $1.9 \pm 0.64$ & $<0.001$ \\
$\begin{array}{l}\text { Phosphorus on } \\
\text { discharge }\end{array}$ & $1.3 \pm 0.39$ & $1.5 \pm 0.37$ & $1.6 \pm 0.60$ & 0.030 \\
\hline $\begin{array}{l}\text { * } p \text {-values are from one-way analysis of variance or Kruskal-Wallis (if there } \\
\text { was evidence of unequal variance for the chronic kidney disease groups). }\end{array}$
\end{tabular}




\section{DISCUSSION}

Chronic non-communicable diseases account for the majority of the morbidity and mortality worldwide, and this is not different in Antigua or the rest of the Caribbean. Based on our review of the Caribbean Renal Registry Report 2006, it was noted that diabetes mellitus and hypertension accounted for the majority of the causes of CKD in the Caribbean $(2,5,6)$. According to Soyibo and Barton (6), the major causes of CKD in Antigua were hypertension (23.3\%), diabetes mellitus $(44.2 \%)$, chronic glomerulonephritis $(14.0 \%)$ and autosomal dominant polycystic kidney disease (4.7\%). This present study revealed that for CKD in Antigua, diabetes mellitus was found to be the most common cause $(51 \%)$, followed by hypertension $(26 \%)$, glomerulonephritis (5\%) and lupus nephritis (4\%). A survey done during the period 2006 to 2009 revealed that the prevalence of diabetes mellitus in Antigua was $37 \%$ and that of hypertension was $69.4 \%$ (7). So, even with a lower prevalence rate in the population, diabetes mellitus accounted for the majority of the causes of CKD in Antigua. Diabetes mellitus was also noted to be the most common cause of CKD in The Bahamas and Trinidad and Tobago, while hypertension was the most common cause in Jamaica, Barbados and the British Virgin Islands $(2,5,6)$.

According to the Pan American Health Organization's Survey of Living Conditions in Antigua during the period 2006 to 2009 , diabetes mellitus and hypertension accounted for $9.6 \%$ and $7.2 \%$ of all deaths, respectively (8). In some of these cases, diabetes mellitus and hypertension were complicated by CKD. This was of serious concern because this age group made up $75 \%$ of the labour force in Antigua (7).

This present study revealed that there were 89 males and 72 females with CKD, with an average age at diagnosis of $56.2 \pm 1.7$ years for males and $59 \pm 1.9$ years for females (Table 1). In an article by Soyibo and Barton (6), in 2007, in Jamaica, there were 968 patients with CKD, 576 of whom were on RRT, with an average age of $54.9 \pm 18.7$ for males and $52.9 \pm 18.2$ for females. There has been a significant increase in the number of patients requiring haemodialysis in Antigua. In Antigua, in 2007, there were 43 patients, 25 males (58.1\%) and 18 females $(41.9 \%)$, on haemodialysis, with an average age of $52.7 \pm 13.7$ years $(6)$. The present study revealed that there were 62 patients on RRT (the average age being $53.3 \pm 14.5$ years (Table 2$)$ ), $92.5 \%$ of whom were on haemodialysis (Table 6).
Haemodialysis treatment is not available in most of the Caribbean countries due to the limited expertise in managing units and unavailable financial resources and support from both the government and the private sector. Patients' selection for RRT modalities in the Caribbean depends on space availability, finances and the presence of co-morbid conditions. In Antigua, there is a Dialysis Committee (which includes nephrologists, a dialysis unit manager and hospital administrators) which decides on the patients who are eligible for chronic haemodialysis. The eligibility criteria are age, comorbidities and functional capacity. Hence, this affects the average age of the patients on haemodialysis. The actual number of patients requiring haemodialysis may be higher than the number currently on haemodialysis. Currently, haemodialysis is the only type of RRT offered in Antigua. This causes a significant economic burden on the society with each dialysis session (including consumables and erythropoietin) costing approximately US\$80 (unpublished data). With $54 \%$ of the patients receiving haemodialysis twice a week and $46 \%$ three times a week, the economic burden is significant.

In light of the increasing number of patients who may require RRT in Antigua and the rest of the Caribbean, peritoneal dialysis and renal transplantation are the other modalities of therapy which should be explored. Cost-effective analyses of RRT modalities should take into account the actual treatment cost and quality of life gained. With improved quality of life, patients are less likely to be absent from work and also more likely to be gainfully employed. In the reports from 2006 and 2007, Caribbean Renal Registry data revealed that peritoneal dialysis was offered only in Trinidad and Tobago, Jamaica, The Bahamas and St Maarten $(2,6)$.

Jamaica and Trinidad and Tobago are the only Caribbean islands which have renal transplantation. Jamaica experienced major challenges in maintaining the transplantation programme mostly because of the high cost of immunosuppressives which had to be sourced by patients which some were unable to sustain. Also, the negative cultural behaviour in the Caribbean towards organ donation could be a contributing factor (5). Trinidad and Tobago has an active transplantation programme which is sustained by its government. A total of 74 patients had undergone living donor kidney transplantation in Trinidad and Tobago between January 2006 and April 2011 (6). Currently, patients in other Caribbean islands explore avenues in the United States of America (USA) to obtain renal transplantation. The 
Caribbean islands can form a pool for kidney donation, and Caribbean governments can formulate an agreement regarding the initiation and sustenance of a Caribbean renal transplantation programme.

Numerous factors contribute to morbidity in patients with CKD. These include anaemia, hypertension, malnutrition, renal osteodystrophy and lipid abnormalities, with their association with an increased risk of cardiovascular disease. In this study, at the time of diagnosis, the average haemoglobin $(\mathrm{g} / \mathrm{dL})$ for males was 10.2 \pm 2.4 and females $9.6 \pm 1.7$ (Table 1). Upon further evaluation, the average initial haemoglobin for patients requiring RRT was $8.7 \pm 1.7$ and $11.0 \pm 1.9$ for those not on RRT (Table 2). When comparing the haemoglobin levels of patients in CKD stages III, IV and V, it was noted that the haemoglobin levels at diagnosis were $11.3 \pm 1.74,10.3 \pm 1.97$ and $8.58 \pm 1.80$, respectively; whereas, when discharged, their haemoglobin levels were $11.1 \pm 1.75,10.7 \pm 1.70$ and $10.5 \pm 1.73$, respectively (Table 8 ). Hence, there was an improvement in the haemoglobin levels in patients with CKD stage $\mathrm{V}$. This is likely to be due to the use of erythropoietin which was provided by the government of Antigua and Barbuda. The use of erythropoietin negates the need for blood transfusion and also reduces the possibility of rejection from allosensitization in the likely event of transplantation. However, the cost of erythropoietin limits its use in some countries.

According to the National Kidney Foundation (NKF) Dialysis Outcomes Quality Initiative (KDOQI) guidelines, the target haemoglobin is $11-12 \mathrm{~g} / \mathrm{dL}$ or haematocrit of $33-36 \%$ for dialysis patients (9). The correction of anaemia in the dialysis population leads to improved clinical outcomes of mortality and decreased hospitalization rates. Of note, anaemia management is also crucial in pre-ESRD patients and among those at an even earlier stage of CKD. Among the patients with CKD, anaemia influences both the pathogenesis of and adverse outcomes from cardiovascular disease. The anaemia of early-stage CKD contributes to the development of left ventricular hypertrophy, which itself is an independent determinant of mortality among patients with ESRD (10). The burden of anaemia is compounded not only by the prevalence of CKD but by its under-recognition and under-treatment. Despite the availability of recombinant erythropoietin for more than a decade, recent data have shown a high prevalence of anaemia among patients with ESRD at the initiation of dialysis (11). In a large cohort of patients who began chronic dialysis in the USA between April 1995 and June 1997,
$51 \%$ of the patients had haematocrit levels less than $28 \%$ and $67 \%$ had haematocrit levels less than 30\% (11). Overall, only $23 \%$ of the patients had received recombinant erythropoietin before the initiation of dialysis, and among the patients with haematocrit levels less than $28 \%$, only $20 \%$ had received recombinant erythropoietin (11). With the recognition of cardiovascular disease as the leading cause of death among patients with CKD and the role of anaemia in its pathogenesis, more attention needs to be directed towards this potentially modifiable risk factor and to ensure the detection and management of anaemia in the pre-dialysis stage of CKD.

On discharge, the average URR was $65.2 \pm 11.3$ for males and $72.9 \pm 11.4$ for females (Table 1). Hence, according to the KDOQI guidelines, dialysis can be considered adequate if URR is greater than $65 \%$ per dialysis session, which is delivered three times per week (12). It has been noted that mortality among ESRD patients was lower when sufficient haemodialysis treatments were provided and the URRs were greater than $65 \%$.

This study's data indicated that when the patients' calcium levels at diagnosis and on discharge were compared based on the CKD stage, patients in CKD stages III and IV were in the recommended range for calcium $(2.25-2.75 \mathrm{mmol} / \mathrm{L})$ based on KDOQI guidelines at the time of diagnosis and at the last time the calcium level was reviewed (Table 8) (13). However, for patients in CKD stage $\mathrm{V}$, the initial calcium level was lower than the target level, and the calcium level on discharge was also below target. Hence, more attention should be placed on calcium level correction in this group. Phosphorus was in the normal range for patients in CKD stages III and IV. Phosphorus was also elevated in the CKD stage V sample at the time of diagnosis, but it was in the recommended range of $1.10-1.80 \mathrm{mmol} / \mathrm{L}$ on discharge (13). Hence, there appears to be an adequate use of the oral phosphate binders, education on dietary phosphate reduction and Vitamin D supplementation for patients with CKD.

The Caribbean Renal Registry data from 2006 revealed that in Jamaica and The Bahamas, $64.8 \%$ and $61.2 \%$ of the patients, respectively, had serum calcium below $2.24 \mathrm{mmol} / \mathrm{L}$ (2). In the British Virgin Islands, Barbados and the Cayman Islands, $61.5 \%, 52.3 \%$ and $65.9 \%$ of the patients respectively had serum calcium within the recommended range, and the level of serum phosphate was also found to be in the normal reference range for $50 \%$ of the patients (2). However, when the calcium phosphate product was calculated, it was found that all the countries had over two-thirds of their patients 
above the recommended value of $4.40 \mathrm{mmol}^{2} / \mathrm{L}^{2}$. The patients with levels above this were at an increased risk of soft tissue and vascular calcification and death. Further, work can be done throughout the Caribbean to achieve the NKF-KDOQI targets for bone and mineral metabolism in patients with CKD in order to reduce the morbidity and the mortality.

Albumin has been used as an indicator of malnutrition in patients with CKD, with a value of $<35 \mathrm{~g} / \mathrm{L}$ indicating a higher risk of morbidity and mortality. In a study conducted in Jamaica in 2012, it was found that the factors associated with malnutrition in patients on dialysis were ESRD due to diabetic nephropathy, dialysis duration for $\leq 6$ months, low serum albumin, pre-dialysis serum creatinine of $880 \mathrm{umol} / \mathrm{L}$, low total cholesterol and the presence of AV fistula access (14). During the study period, at the time of diagnosis of CKD, the albumin level $(\mathrm{g} / \mathrm{L})$ was $34 \pm 8.7$ for males and $33 \pm 7.3$ for females (Table 1). These results suggest the likely presence of malnutrition in the sample studied.

Of the patients studied, $51.6 \%$ had dyslipidaemia (Table 9), their average body mass index was $26 \mathrm{~kg} / \mathrm{m}^{2}$ (Table 1), and $10.8 \%$ reported a past or present smoking history (Table 9). These factors, compounded by the fact that the majority of patients had diabetes mellitus and/ or hypertension and that ESRD is a cardiovascular risk equivalent, resulted in significant cardiovascular morbidity and mortality. Consequently, $5.1 \%$ of the patients had myocardial infarction, $12.7 \%$ had unstable angina, $15.3 \%$ had heart failure, and $12 \%$ had ischaemic strokes (Table 9).

A review of the percentage of the patients on RRT who were admitted to hospital versus those not on RRT who were admitted indicated that $41.3 \%$ of the patients on RRT had not been admitted over the period of this study, whereas it was $33.3 \%$ for the patients not on RRT (Table 10). Of the patients not on RRT, $40.3 \%$ had one hospital admission; $20 \%$ of the patients on RRT had at least three hospital admissions, and there was a higher incidence of death among these patients. According to the data from the Caribbean Renal Registry, in 2006, the mortality rate reported for Jamaica was 56 per 1000 patients with ESRD on RRT and 18 per 1000 patients with ESRD for Trinidad and Tobago (2). The Bahamas reported a mortality of 242 per 1000 patients with ESRD. It was thought that the total number of deaths reported for 2006 might have been underestimated for some countries (2). In Antigua, 18 deaths were noted during the study period. This is thought to be an underestimation. The cause of death was presumed in some cases, and the post mortem rate was low. Some patients' records were also missing, and death records were not sourced for all the patients. However, for the data analysed, myocardial infarction resulted in 16.7\% of all deaths, equalling catheter sepsis as the leading cause of mortality in the patients with CKD in Antigua during the study period (2005-13) (Table 4). This was followed by $11.1 \%$ for other infections, including lower respiratory tract infections, urinary tract infections, infective endocarditis and infected diabetic foot. Stroke also accounted for $11.1 \%$ of the deaths.

Table 9: Prevalence of chronic kidney disease risk factors and associated morbidity factors for males, females and total sample

\begin{tabular}{lccc}
\hline $\begin{array}{l}\text { Chronic kidney disease } \\
\text { risk factors and associated } \\
\text { morbidity factors }\end{array}$ & $\begin{array}{c}\text { Males } \\
\text { Number (\%) }\end{array}$ & $\begin{array}{c}\text { Females } \\
\text { Number (\%) }\end{array}$ & $\begin{array}{c}\text { Total } \\
\text { Number (\%) }\end{array}$ \\
\hline Diabetes mellitus (DM) & $47(52.8)$ & $43(60.6)$ & $90(56.3)$ \\
Hypertension (HTN) & $55(61.8)$ & $54(76.1)$ & $109(68.1)$ \\
DM and HTN & $33(37.1)$ & $35(49.3)$ & $68(42.5)$ \\
HIV & $1(1.1)$ & 0 & $1(0.6)$ \\
Systemic lupus & 0 & $5(7.0)$ & $5(3.1)$ \\
erythematosus* & & & \\
Polycystic kidney disease & $2(2.3)$ & 0 & $2(1.3)$ \\
Stable angina & $6(6.7)$ & $6(8.6)$ & $12(7.6)$ \\
Unstable angina & $10(11.4)$ & $10(14.3)$ & $20(12.7)$ \\
Myocardial infarction & $6(6.8)$ & $2(2.9)$ & $8(5.1)$ \\
Heart failure & $8(9.1)$ & $16(23.2)$ & $24(15.3)$ \\
Ischaemic stroke & $13(14.8)$ & $6(8.5)$ & $19(12.0)$ \\
Haemorrhagic stroke & $1(1.1)$ & $1(1.4)$ & $2(1.3)$ \\
Dyslipidaemia & $40(45.5)$ & $41(59.4)$ & $81(51.6)$ \\
Cigarette smoking & $11(12.6)$ & $6(8.5)$ & $17(10.8)$ \\
\hline
\end{tabular}

$* p<0.05$

Table 10: Infections, number of hospital admissions and deaths in patients on renal replacement therapy versus those not on renal replacement therapy

\begin{tabular}{|c|c|c|c|c|}
\hline & $\begin{array}{c}\text { Patients } \\
\text { on renal } \\
\text { replacement } \\
\text { therapy } \\
\text { Number }(\%) \\
\end{array}$ & $\begin{array}{c}\text { Patients not } \\
\text { on renal } \\
\text { replacement } \\
\text { therapy } \\
\text { Number }(\%) \\
\end{array}$ & $\begin{array}{c}\text { Total } \\
\text { Number }(\%)\end{array}$ & $p$-value \\
\hline Catheter sepsis & $12(15.8)$ & N/A & $12(8.1)$ & $<0.001$ \\
\hline $\begin{array}{l}\text { Lower respiratory } \\
\text { tract infection }\end{array}$ & $6(7.9)$ & $2(2.8)$ & $8(5.4)$ & 0.277 \\
\hline Endocarditis & $1(1.1)$ & 0 & $1(0.1)$ & 1.000 \\
\hline $\begin{array}{l}\text { Number of hospital } \\
\text { admissions }\end{array}$ & & & & $<0.001$ \\
\hline 0 & $31(41.3)$ & $24(33.3)$ & $55(37.4)$ & \\
\hline 1 & $12(16)$ & $29(40.3)$ & $41(27.9)$ & \\
\hline 2 & $17(22.7)$ & $18(25.0)$ & $35(23.8)$ & \\
\hline 3 & $8(10.7)$ & $1(1.4)$ & $9(6.1)$ & \\
\hline 4 & $6(8)$ & 0 & $6(4.1)$ & \\
\hline 5 & $1(1.3)$ & 0 & $1(0.7)$ & \\
\hline Deaths & $14(18.2)$ & $1(1.4)$ & $15(10.1)$ & 0.001 \\
\hline
\end{tabular}


Chronic kidney disease is associated with a higher prevalence of ischaemic heart disease and increases the risk of death among individuals with pre-existing coronary disease. Cardiovascular mortality is $10-30$ times higher in individuals with ESRD than in the general population when matched for age, ethnic origin and gender (3). The association between CKD and an increased risk of cardiovascular disease is observed in high-risk groups and in people in the general population with low glomerular filtration rates and albuminuria. To reduce the morbidity and mortality due to ischaemic heart disease, there should be optimization of all risk factors including blood glucose, blood pressure and dyslipidaemia. The average body mass index noted for study participants was $25.2 \pm 4.5$ for males and $27.0 \pm$ 5.0 for females (Table 1). Hence, the population studied consisted mainly of overweight and obese patients who usually have associated comorbidities and subsequent development of other complications. Lifestyle modifications, obesity control through healthy eating and increased physical activity will help to reduce the exponentially increasing and overwhelming burden of renal failure in the Caribbean. All smokers should be advised about smoking cessation. This study's data revealed that $10.8 \%$ of the patients had a past or present history of cigarette smoking (Table 9). In Jamaica, in 2006, according to data from the Caribbean Renal Registry, $85.8 \%$ of the patients reported never having smoked before while $4.6 \%$ were currently smoking and $9.6 \%$ were former smokers (2).

Regarding catheter sepsis, sterile conditions should be ensured during catheter placement, and attachment to the dialysis machines. Patients should be informed to avoid handling catheters between dialysis sessions. Also, the period between haemodialysis catheter insertion and fistula placement prior to dialysis initiation should be minimized. Of note, at the end of this study period, $81 \%$ of the patients had AV fistulas (Fig. 2).

During the study period, the number of patients seen at MSJMC with CKD increased from 2006 to 2010 (Table 7). There were increased referrals from health centres and private physician offices for continued specialty management on the assumption of duty of a nephrologist at MSJMC. Complications related to CKD/ ESRD, though treatable by nephrologists, can be treated by primary care physicians and internists. Guidance should be provided by nephrologists. However, with the increasing numbers of patients with CKD and ESRD, the ratio of patients to nephrologists will increase significantly. Hence, internists and general practitioners should be educated regarding the management of patients with CKD. Most cases of non-progressive CKD could be managed by general practitioners. Nephrology referral could be reserved for patients with advanced-stage CKD, rapidly declining kidney function, persistent proteinuria, uncontrolled hypertension or diabetes mellitus.

During the pre-dialysis period, a holistic approach is required to minimize the morbidity and mortality seen in patients with CKD. It is crucial that patients be referred to a nephrologist, dietician, social worker and mental health professional (if patients are exhibiting signs of depression). During this period, patients should also be educated about the various modes of RRT and provided with information on dialysis access, nutritional modifications, possible nephrotoxic drugs and potential financial support for the services they need.

It is imperative that we urgently develop preventative programmes for CKD as well as for the two leading chronic non-communicable diseases that cause kidney disease, namely diabetes mellitus and hypertension. Lifestyle changes, as well as a massive and sustained community education initiative which has a screening aspect as an integral part, will be needed. The Caribbean Renal Registry and national kidney registries have assisted in outlining the impact of CKD and ESRD in the Caribbean. The information gathered can be used to guide the governments in the Caribbean in addressing this issue which is growing at an exponential rate and will only increase due to the global impact of non-communicable diseases.

To highlight this, in this study, it was noted that $41.56 \%$ of the patients were at CKD stage V (Table 5). Hence, more aggressive screening should be done to avoid late presentation of patients to a nephrologist. This study demonstrated that risk factors for advanced CKD included diabetes mellitus and hypertension. Patients with these diseases should be screened regularly for significant kidney dysfunction with a spot urine albumin-to-creatinine ratio and with serum creatinine measurement for the estimation of glomerular filtration rate. Indeed, early identification and aggressive management of CKD are important in the effort to reduce the significant clinical and economic burden of this disease.

\section{REFERENCES}

1. Kidney Disease: Improving Global Outcomes (KDIGO) CKD Work Group. KDIGO 2012 clinical practice guideline for the evaluation and management of chronic kidney disease. Kidney Int Suppl 2013; 3: $1-150$.

2. Soyibo AK, Barton EN. Report from the Caribbean Renal Registry, 2006. West Indian Med J 2007; 56: 355-63. 
3. Lozano R, Naghavi M, Foreman K, Lim S, Shibuya K, Aboyans V et al. Global and regional mortality from 235 causes of death for 20 age groups in 1990 and 2010: a systematic analysis for the Global Burden of Disease Study 2010. Lancet 2012; 380: 2095-128.

4. Consensus Development Conference Panel. Morbidity and mortality of renal dialysis: an NIH consensus conference statement. Ann Intern Med 1994; 121: 62-70.

5. Soyibo AK, Roberts L, Douglas LL, Barton EN. Renal disease in the Caribbean: the disease of the past, present and future. West Indian Med J 2012; 61: 418-21.

6. Soyibo AK, Barton EN. Chronic renal failure from the English-speaking Caribbean: 2007 data. West Indian Med J 2009; 58: 596-600.

7. Pan American Health Organization. Health in the Americas. Washington, DC: PAHO; 2012.

8. Pan American Health Organization. Health in the Americas, 2012 Edition: Country Volume - Antigua and Barbuda. 2012. Available from: www.paho.org/salud-en-las-americas-2012/dmdocuments/hia2012-ant-barbuda.pdf?ua=1.

\section{APPENDIX \\ CHRONIC KIDNEY DISEASE IN ANTIGUA: MORBIDITY AND MORTALITY FACTORS DATA ENTRY SHEET}

- Patient identification number:

- Gender:

- Date of birth (dd/mm/year): Age (years): ....

- Ethnicity:

(i) African descent

(ii) Caucasian

(iii) Asian

(iv) Hispanic

(v) Other: (please specify)

- Employed? (Y/N):

- Date of diagnosis of renal disease:

- Stage of chronic kidney disease (CKD) (MDRD):

- Creatinine at time of diagnosis:

- Urea at time of diagnosis:

- Haemoglobin at time of diagnosis:

- Albumin at time of diagnosis:

- Corrected calcium at time of diagnosis:

- Uric acid at time of diagnosis:

- Phosphorus at time of diagnosis:

- Kidney size on KUB U/S: Right ...... cm Left ...... cm

- Body mass index:

- Renal replacement therapy needed $(\mathrm{Y} / \mathrm{N})$ :
9. National Kidney Foundation-Dialysis Outcomes Quality Initiative. NKF-DOQI clinical practice guidelines for the treatment of anaemia of chronic renal failure. Am J Kidney Dis 1997; 30 (Suppl 3): S192-240.

10. Foley RN, Parfrey PS, Harnett JD, Kent GM, Martin CJ, Murray DC et al. Clinical and echocardiographic disease in patients starting end-stage renal disease therapy. Kidney Int 1995; 47: 186-92.

11. Obrador GT, Ruthazer R, Arora P, Kausz AT, Pereira BJ. Prevalence of and factors associated with suboptimal care before initiation of dialysis in the United States. J Am Soc Nephrol 1999; 10: 1793-800.

12. National Kidney Foundation. NKF-K/DOQI clinical practice guidelines for haemodialysis adequacy: update 2000. Am J Kidney Dis 2001; 37 (suppl 1): S7-64.

13. National Kidney Foundation. K/DOQI clinical practice guidelines for bone metabolism and disease in chronic kidney disease. Am J Kidney Dis 2003; 42 (suppl 3): S1-201.

14. Dewar D, Soyibo AK, Barton EN. Nutritional markers in patients undergoing chronic haemodialysis in Jamaica. West Indian Med J 2012; 61: 284-9.

- Type of renal replacement therapy:

Vascular access type (permanent/temporary catheter \& site):

Arteriovenous fistula $(\mathrm{Y} / \mathrm{N})$ :

Arteriovenous graft $(\mathrm{Y} / \mathrm{N})$ :

- Frequency of dialysis:

- Co-morbid conditions which may cause CKD:

o History of hypertension (Y/N):

o History of diabetes mellitus $(\mathrm{Y} / \mathrm{N})$ :

o History of diabetes mellitus and hypertension $(\mathrm{Y} / \mathrm{N})$ :

o History of systemic lupus erythromatosus $(\mathrm{Y} / \mathrm{N})$ :

o History of HIV $(\mathrm{Y} / \mathrm{N})$ :

o History of sickle cell disease $(\mathrm{Y} / \mathrm{N})$ :

o History of polycystic kidney disease $(\mathrm{Y} / \mathrm{N})$ :

o History of chronic glomerulonephritis $(\mathrm{Y} / \mathrm{N})$ :

o History of lupus nephritis $(\mathrm{Y} / \mathrm{N})$ :

o Other: (please specify)

- Cause of CKD:

o Physician documented cause of CKD:

o $\mathrm{CKD}$ due to hypertension $(\mathrm{Y} / \mathrm{N})$ :

o $\mathrm{CKD}$ due to diabetes mellitus $(\mathrm{Y} / \mathrm{N})$ :

o CKD due to systemic lupus erythromatosus $(\mathrm{Y} / \mathrm{N})$ : 
o CKD due to $\mathrm{HIV}$ (Y/N):

o CKD due to sickle cell disease $(\mathrm{Y} / \mathrm{N})$ :

o CKD due to polycystic kidney disease $(\mathrm{Y} / \mathrm{N})$ :

o $\mathrm{CKD}$ due to chronic glomerulonephritis $(\mathrm{Y} / \mathrm{N}): \ldots$

o $\mathrm{CKD}$ due to lupus nephritis $(\mathrm{Y} / \mathrm{N})$ :

o Other cause of CKD: (please specify)

- Risk factors for cardiovascular disease

Stable angina $(\mathrm{Y} / \mathrm{N})$ :

Unstable angina $(\mathrm{Y} / \mathrm{N})$ :

History of myocardial infarction $(\mathrm{Y} / \mathrm{N})$ :

Valvular heart disease $(\mathrm{Y} / \mathrm{N})$ :

Cardiomyopathy $(\mathrm{Y} / \mathrm{N})$ :

Heart failure $(\mathrm{Y} / \mathrm{N})$ :

Pericardial effusion/cardiac tamponade $(\mathrm{Y} / \mathrm{N})$ :

History of ischaemic stroke $(\mathrm{Y} / \mathrm{N})$ :

History of haemorrhagic stroke (Y/N):

History of cigarette smoking $(\mathrm{Y} / \mathrm{N})$ :

History of dyslipidaemia $(\mathrm{Y} / \mathrm{N})$ :

Family history of sudden cardiac death $(\mathrm{Y} / \mathrm{N})$ :

- Infection $(\mathrm{Y} / \mathrm{N})$ : (specify type)

- Haemoglobin level on discharge $(\mathrm{g} / \mathrm{dL})$ :
- Erythropoetin use $(\mathrm{Y} / \mathrm{N})$ :

- Creatinine level on discharge (mmol/L):

- Urea reduction ratio on discharge (\%):

- Albumin level on discharge $(\mathrm{g} / \mathrm{dL})$ :

- Corrected calcium on discharge $(\mathrm{mmol} / \mathrm{L})$ :

- Phosphorus level on discharge ( $\mathrm{mmol} / \mathrm{L})$ :

- Potassium level on discharge ( $\mathrm{mmol} / \mathrm{L})$ :

- Discharged alive or deceased:

- Discharge diagnosis:

- Previous hospital admission $(\mathrm{Y} / \mathrm{N})$ :

- Admit once $(\mathrm{Y} / \mathrm{N})$ :

- Admit once final diagnosis:

- Admit twice (Y/N):

- Admit twice final diagnoses:

- Admit three times $(\mathrm{Y} / \mathrm{N})$ :

- Final diagnoses for three hospital admissions:

- Admit $>3$ times $(\mathrm{Y} / \mathrm{N})$ :

- Total number of hospital admissions:

- Primary cause of death:

- Underlying cause of death:

- Other conditions related to death: 